\title{
Sonographic evaluation of fetal scrotum, testes and epididymis
}

\author{
Álvaro López Soto, MD, PhD, Jose Luis Meseguer González, MD, María Velasco Martínez, MD, \\ Rocío López Pérez, MD, PhD, Inmaculada Martínez Rivero, MD, Mónica Lorente Fernández, MD, \\ Olivia García Izquierdo, MD, Juan Pedro Martínez Cendán, MD, PhD \\ Prenatal Diagnosis Unit, Department of Obstetrics, Hospital General Universitario Santa Lucía, Cartagena, Spain
}

External male genitalia have rarely been evaluated on fetal ultrasound. Apart from visualization of the penis for fetal sex determination, there are no specific instructions or recommendations from scientific societies. This study aimed to review the current knowledge about prenatal diagnosis of the scrotum and internal structures, with discussion regarding technical aspects and clinical management. We conducted an article search in Medline, EMBASE, Scopus, Google Scholar, and Web of Science databases for studies in English or Spanish language that discussed prenatal scrotal pathologies. We identified 72 studies that met the inclusion criteria. Relevant data were grouped into sections of embryology, ultrasound, pathology, and prenatal diagnosis. The scrotum and internal structures show a wide range of pathologies, with varying degrees of prevalence and morbidity. Most of the reported cases have described incidental findings diagnosed via striking ultrasound signs. Studies discussing normative data or management are scarce.

Keywords: Prenatal diagnosis; Sonography; Urogenital system; Scrotum; Cryptorchidism

\section{Introduction}

Prenatal diagnosis of genital anomalies involves evaluation of fetal genitalia. Traditionally, it has been given little importance beyond fetal sex determination. Moreover, there are no associated guidelines or specific recommendations by scientific societies [1-3]. Considering this scant attention, the scrotal sac and its contents are one of the least studied fetal structures. A probable reason is that testicular descent does not occur until the 24th week of gestation, leading to a missed opportunity to review them in the mid-trimester ultrasound $[4,5]$. However, the testes play an important role in male fetal development and there are several significant pathologies that can be diagnosed during pregnancy including meconium periorchitis (MPO), intrauterine testicular torsion (IUTT), inguinoscrotal hernia, or cryptorchidism, which is the most common congenital anomaly in male newborns [6-10]. The objective of this study was to review the current knowledge about prenatal diagnosis of pathologies related to the scrotum and internal structures, with discussion regarding ultrasonography, morphometry, pathology, and clinical management.

\section{Methods}

We conducted an article search in the Medline, EMBASE, Scopus, Google Scholar, and Web of Science databases for original studies, reviews, or clinical case reports that discussed the prenatal diagnosis of pathologies related to the scrotum, testes, and/or epididymis. A combination of relevant Medical Subject Headings terms, keywords, and word variants for "fetal scrotum," "fetal testes," "fetal medicine," and "prenatal ultrasound" were used. We included articles

Received: 2021.01.23. Revised: 2021.03.14. Accepted: 2021.06.15. Corresponding author: Álvaro López Soto, $\mathrm{MD}, \mathrm{PhD}$

Prenatal Diagnosis Unit, Department of Obstetrics, Hospital General Universitario Santa Lucía, 001 Minarete Street, Cartagena 30202, Spain

E-mail: alvarolopezsoto1@gmail.com

https://orcid.org/0000-0002-3314-0347

Articles published in Obstet Gynecol Sci are open-access, distributed under the terms of the Creative Commons Attribution Non-Commercial License (http://creativecommons. org/licenses/by-nc/3.0/) which permits unrestricted non-commercial use, distribution, and reproduction in any medium, provided the original work is properly cited.

Copyright $\odot 2021$ Korean Society of Obstetrics and Gynecology 


\section{Obstetrics \& Gynecology Science}

Vol. 64, No. 5, 2021

published between 2000 and 2021. Studies published in languages other than English or Spanish were excluded. Two expert authors independently evaluated the articles.

\section{Results}

We identified 72 studies that met the inclusion criteria. We have synthesized all the relevant information and data in the following sections: embryology, ultrasound, pathology, and prenatal diagnosis.

\section{Embryology}

During the early stages of organogenesis, three basic structures are formed: bipotential gonads, mesonephric cords, and undifferentiated external genitalia including the phallus and the labioscrotal folds. Presence of the SRY gene on the $\mathrm{Y}$ chromosome initiates male sex determination and testosterone production. Its androgenic influence results in a differentiation process wherein the gonads form the testicles; the mesonephric cords form the epididymis, vas deferens, and seminal glands; phallus elongates and differentiates into penis; and the labioscrotal folds fuse to form the scrotum $[11,12]$

Testicular migration begins in the 8th week of gestation and continues until the 35th week $[13,14]$. It consists of two distinct stages. The first occurs in the abdominal region and is based on the difference between linear fetal growth and the traction exerted by the gubernacular bulb anchored in the scrotum. This stage occurs between the 10th and 15th weeks and is hormonally governed by insulin-like hormone 3 produced by the Leydig cells $[15,16]$. The second inguinal stage is mainly controlled by androgens through their effect on masculinization of the femoral-inguinal nerve [16]. It starts in the 20th week and is usually a relatively quick process that lasts for 3 to 4 weeks [14].

\section{Ultrasound}

To the best of our knowledge, there seems to be no detailed description in the medical literature about fetal ultrasound of the scrotum and its internal structures. The only study on technical aspects is by Fait et al. [17], which discussed correct

Table 1. Anatomical measurements by gestational age

\begin{tabular}{lccccc}
\hline $\begin{array}{c}\text { Gestational } \\
\text { age (wks) }\end{array}$ & $\begin{array}{c}\text { Scrotal circumfer- } \\
\text { ence }(\mathbf{m m})[\mathbf{4}]\end{array}$ & $\begin{array}{c}\text { Scrotal diameter } \\
(\mathbf{m m})[\mathbf{2 1}]\end{array}$ & $\begin{array}{c}\text { Testicular diameter } \\
(\mathbf{m m})[\mathbf{2 2}]\end{array}$ & $\begin{array}{c}\text { Testicular length } \\
(\mathbf{m m})[\mathbf{2 3}]\end{array}$ & $\begin{array}{c}\text { Testicular width } \\
(\mathbf{m m})[\mathbf{2 3}]\end{array}$ \\
\cline { 2 - 6 } & Ultrasound & Ultrasound & Ultrasound & Anatomy & Anatomy \\
\hline 8 & - & - & - & 2.1 & 0.2 \\
10 & - & - & - & 3.8 & 1.0 \\
12 & - & - & - & 4.2 & 1.9 \\
14 & 16.63 & 3.7 & - & 5.0 & 2.0 \\
16 & 19.75 & 5.1 & - & 5.8 & 2.2 \\
18 & 24.29 & 6.7 & - & 6.0 & 2.9 \\
20 & 28.53 & 8.3 & - & 6.0 & 3.0 \\
22 & 34.09 & 10.2 & - & 6.6 & 3.5 \\
24 & 40.90 & 12.3 & 6.3 & - & - \\
26 & 48.72 & 14.6 & 7.3 & - & - \\
28 & 58.62 & 17.3 & 8.7 & - & - \\
30 & 70.34 & 20.4 & 10.4 & - & - \\
32 & 84.02 & 24.0 & 11.9 & - & - \\
34 & 101.09 & 27.9 & 13.6 & - & - \\
36 & 118.62 & 31.9 & 15.5 & - & - \\
38 & - & 35.6 & 17.7 & - & - \\
40 & - & 38.8 & 20.0 & - & - \\
\hline
\end{tabular}




\section{Obstetrics \& Gynecology Science}

Álvaro López Soto, et al. Sonographic evaluation of fetal scrotum

visualization of the scrotum and testicles in late pregnancy. Ultrasound exploration is usually possible in $100 \%$ of the patients between 34th and 36th weeks of gestation and the possibility gradually declines to $71.4 \%$ in the 40 th week. Factors that prevent optimal visualization of the scrotum include decreased amniotic fluid and unfavorable fetal position. In contrast, postnatal scrotal ultrasound is a fully standardized technique that is widely used in pediatrics and urology [18-20].

There is a very limited amount of literature on morphometric measurements of male genital growth throughout pregnancy except the examination of fetal penis. Two studies measured the scrotum using different techniques. Achiron et al. [4] performed a measurement of the scrotal circumference from the outer edge. Pinette et al. [21] opted for a transverse measurement at the widest point and also from edge to edge. Only one study has been conducted on testicular size [22]. Rotondi et al. [22] used the maximum testicular diameter obtained from the 25th to the 40th week. Other anatomical studies combined two or more measures among length, width, thickness, or weight $[23,24]$. Postnatal scrotal ultrasound allows the evaluation of all of the aforementioned measures including testicular volume [25]. All of these studies have reported a high correlation between anatomical measurements and gestational age (Table 1) [4,21-24].

Important ultrasound findings include the absence of descended testicles, morphological abnormalities, and presence of scrotal masses. Testicular descent is the main qualitative change that can be assessed throughout pregnancy. There are several publications that have reviewed testicular descent using ultrasound $[4,5,7,17,26]$, magnetic resonance [27], or anatomical studies [28]. All of these studies agree that descent begins at 24th to 25 th week in $5 \%$ of the cases and ends at 32 nd to 33 rd week in $97 \%$ of the fetuses $[4,7,17]$. The remaining $3 \%$ of the cases correspond to undescended testicles or cryptorchidism [17]. The descent is usually bilateral, with less than $6 \%$ asymmetry and the right testicle seems to be the first to complete the migration [28]. Morphological abnormalities include alterations in the position, number, or form of the scrotum or testicles. These include bifid scrotum, scrotoschisis, or penoscrotal anomalies [29-31]. Scrotal masses can exhibit all types of morphologies including solid or cystic appearance, calcification, peristaltic movement, or presence of blood flow on Doppler ultrasound. They could correspond to testicular or paratesticular tumors such as teratomas, rhabdomyosarcomas, hemangiomas, lymphomas, or metastases. Other abnormalities such as hydrocele, hematocele, meconial ascites, pseudocysts, inguinoscrotal hernia, or testicular torsion could also be observed [32-34].

\section{Pathology}

There are many pathologies with varying degrees of frequency (Table 2). Although they may be interrelated, we have grouped the entities according to the main structures involved.

\section{1) Scrotal pathologies}

We have included morphological anomalies as well as the presence of scrotal masses.

\section{Morphological abnormalities}

Scrotal morphological pathologies include a group of rare anomalies whose etiology is not fully understood. However, the main theory is that they occur due to disruption during early division and migration of the labioscrotal folds [35,36]. The main recognized entities include scrotal transposition,

Table 2. Prevalence of the main pathologies sorted by the order of frequency

\begin{tabular}{lc}
\hline Pathology & Prevalence \\
\hline Testicular appendage (\%) & $80-100$ \\
Epididymal appendage (\%) & $20-24$ \\
Hydrocele (\%) & 15 \\
Epididymal cyst (\%) & 14.4 \\
Epididymal attachment anomalies (\%) & 3.44 \\
Cryptorchidism (\%) & $2-3.4$ \\
Testicular litiasis (\%) & 2.9 \\
Inguinoescrotal hernia (\%) & $0.8-4.4$ \\
Congenital anorchia & $1: 20.000$ births \\
Meconial periorchitis & $1: 35.000$ births \\
Sacrococcygeal teratoma & $1: 40.000$ births \\
Polyorchidism & $>200$ cases reported \\
Intrauterine testicular torsion & $>150$ cases reported \\
Transposition penoscrotal & $>100$ cases reported \\
Scrotoschisis & $<50$ cases reported \\
Accesory scrotum & $<50$ cases reported \\
Scrotal agenesis & $<10$ cases reported \\
Testicular teratoma & $<10$ cases reported \\
Granulosa cell tumor & $<10$ cases reported \\
\hline
\end{tabular}




\section{Obstetrics \& Gynecology Science}

Vol. 64, No. 5, 2021

bifid scrotum, accessory scrotum, and scrotal agenesis as well as other minor ones such as central scrotalization of the middle raphe or wide penoscrotal distance (Figs. 1 and 2) [31]. One of the main issues is the presence of associated anomalies. Accessory scrotum and ectopic scrotum are usually associated with contiguous subcutaneous tumors [37,38], bifid scrotum is usually associated with scrotal or perineal hypospadias [39], and the most serious cases such as penoscrotal transposition are usually associated with severe malformations of the genitourinary, intestinal, cardiovascular, and skeletal systems [36,40-42]. Scrotal abnormalities, especially the bifid scrotum, may occur due to undervirilization, since lip fusion is governed by androgens. Therefore, it could represent a disorder of sex development (DSD) $[43,44]$. Mild and isolated defects such as accessory scrotum or scrotal agenesis

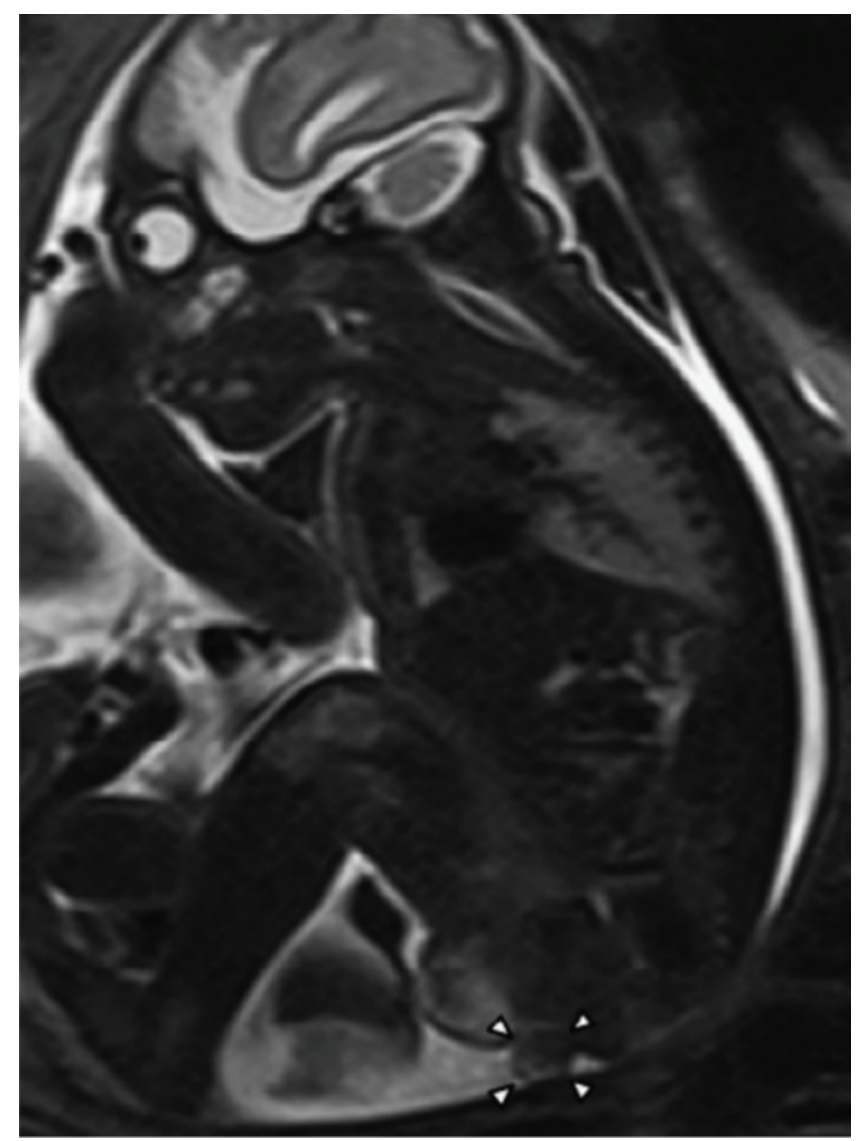

Fig. 1. Magnetic resonance imaging at 31 weeks of gestation. Arrowheads indicate a $1.0 \times 1.2 \mathrm{~cm}$ mass located posterior to the scrotum corresponding to a perineal lipoma (reprinted with permission from Murase N, Uchida H, Hiramatsu K. Accessory scrotum with perineal lipoma diagnosed prenatally: case report and review of the literature. Nagoya J Med Sci 2015;77:501-6) [38]. have a good prognosis and treatment could be surgical or even conservative with topical androgen creams [45-47]. More serious defects such as complete transposition require corrective surgery as well as a complete assessment of the rest of the anomalies $[36,48]$.

\section{Scrotal masses}

Rhabdomyosarcoma is the most common solid scrotal mass in childhood, which accounts for $75 \%$ of all pediatric scrotal cases [49]. Other less frequent tumors include hemangiomas, lipomas, lipoblastomas, and scrotal pearls [18,34,50-52]. Prenatal diagnosis of these entities is practically null because of their small size, being diagnosed in the context of other more obvious anomalies such as an accessory scrotum [53].

Hydrocele, MPO, and inguinoscrotal hernias can also be detected using ultrasound. Hydrocele is the presence of fluid within the scrotum [54]. It is considered the most common finding, with a prevalence of $15 \%$ in fetuses [55]. Ultrasound imaging shows a crescent image surrounding the testicles [32]. The vaginal process is permeable throughout pregnancy and a small amount of peritoneal fluid can reach the scrotal sac, leading to scrotal hydrocele. Hence, it is usually believed that hydrocele does not produce significant sequelae [55]. However, there have been no recent studies on this issue. One of the few studies showed that $13.5 \%$ of the cases were associated with epididymal abnormalities [56].

MPO is caused by fetal meconium peritonitis, with subsequent passage of the meconium to the scrotum through the permeable vaginal process (Fig. 3) [57]. Its estimated incidence is 1 in 35,000 live births [58]. Normally, it is diagnosed
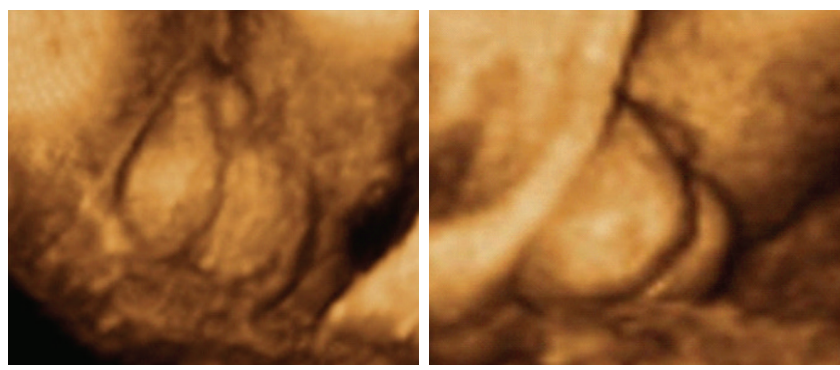

Fig. 2. Penoscrotal hypospadias assessed with three-dimensional ultrasonography in rendering mode at 33 weeks of pregnancy, showing a short penis and evidence of testicles inside a bifid scrotum (arrows) (reprinted with permission from Rios LT, Araujo Júnior E, Nardozza LM, Caetano AC, Moron AF, Martins Mda G. Prenatal diagnosis and postnatal ultrasound findings of cloacal anomaly: a case report. Case Rep Pediatr 2012;2012:969860) [59]. 


\section{Obstetrics \& Gynecology Science}

Álvaro López Soto, et al. Sonographic evaluation of fetal scrotum

at birth and usually presents as a soft scrotal swelling, hard testicular masses, or hydrocele [10]. Prenatal ultrasound signs for diagnosis include fetal ascites associated with bilateral hydrocele and peritesticular calcification [60-63]. Cystic fibrosis has been observed in up to $15 \%$ of the cases. Therefore, screening for this disease is recommended [64]. In asymptomatic masses, conservative management may be adopted while waiting for spontaneous resolution [33]. Surgery is recommended in symptomatic cases or in patients with suspected eoplasm [65].

Inguinoscrotal hernia is a relatively common postnatal finding with an incidence of $1-4 \%$, increasing up to $40 \%$ in extremely premature infants (Fig. 4) [66]. Prenatal diagnosis is extremely limited with approximately 20 published cases [9]. The reason for this disparity is the lack of intra-abdominal pressure during pregnancy [67]. One of the most important associated factors is prematurity, with an incidence 20 times greater in infants weighing less than 1,500 $\mathrm{g}$ and a high prevalence of incarceration. This is due to the failure of obliteration of the vaginal process that normally occurs in the last weeks of gestation $[68,69]$. The pathognomonic sign on ultrasound is the presence of intestinal handles in the scrotal sac [9]. Peripheral displacement of the testicles and absence of flow within the mass can also be observed $[68,70,71]$. The preferred treatment for hernia is surgery, which is performed shortly after the diagnosis due to the risk of incarceration [69].

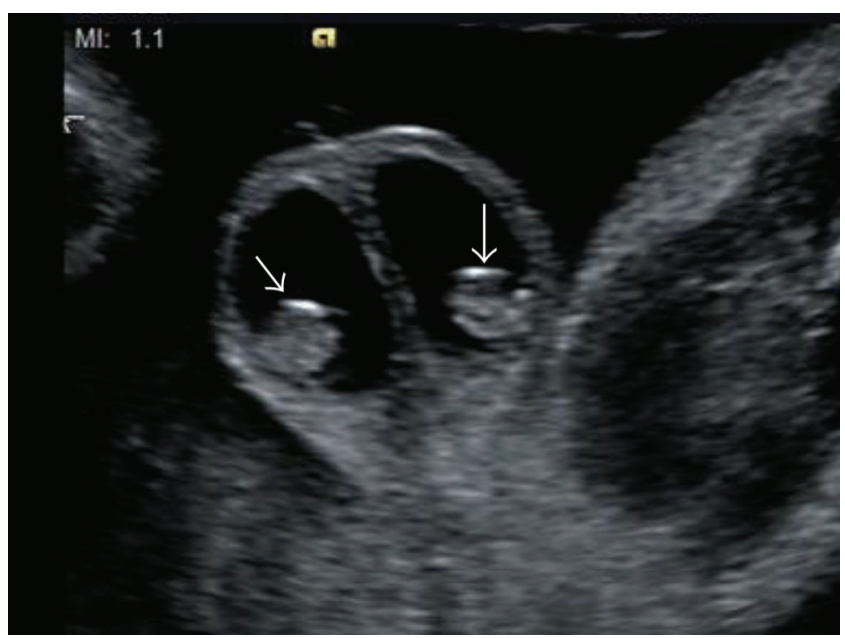

Fig. 3. Bilateral hydrocele with peritesticular calcification at 28 weeks of gestation, suggesting a meconium periorchitis (arrows) (reprinted with permission from Ochiai D, Omori S, Ikeda T, Yakubo $\mathrm{K}$, Fukuiya T. A rare case of meconium periorchitis diagnosed in utero. Case Rep Obstet Gynecol 2015;2015:606134) [61].

\section{Other entities}

Some pathologies with a much lower incidence that deserve a mention include hematocele after adrenal hemorrhage [72], presence of splenic or adrenal ectopic tissue [73-76], and even the scrotal location of a parasitic twin in the entity known as fetus-in-fetu [77].

We would also like to highlight sacrococcygeal teratoma, which is the most frequent extragonadal germ tumor with an incidence of 1 in 40,000 live births [78]. Although it develops at the tip of the sacrum, it can reach a large size extending through the perineum and is often confused with a scrotal mass with a characteristic complex structure $[32,70]$. Its nature is benign and the risk factors are related more closely to its size and the speed of growth. In extreme cases, it can cause complications such as fetal edema or heart failure that require early delivery and elective cesarean section or even EXIT surgery [79].

\section{1) Testicular pathologies}

Cryptorchidism is the main testicular pathology, which is the most common congenital anomaly in male newborns [80].

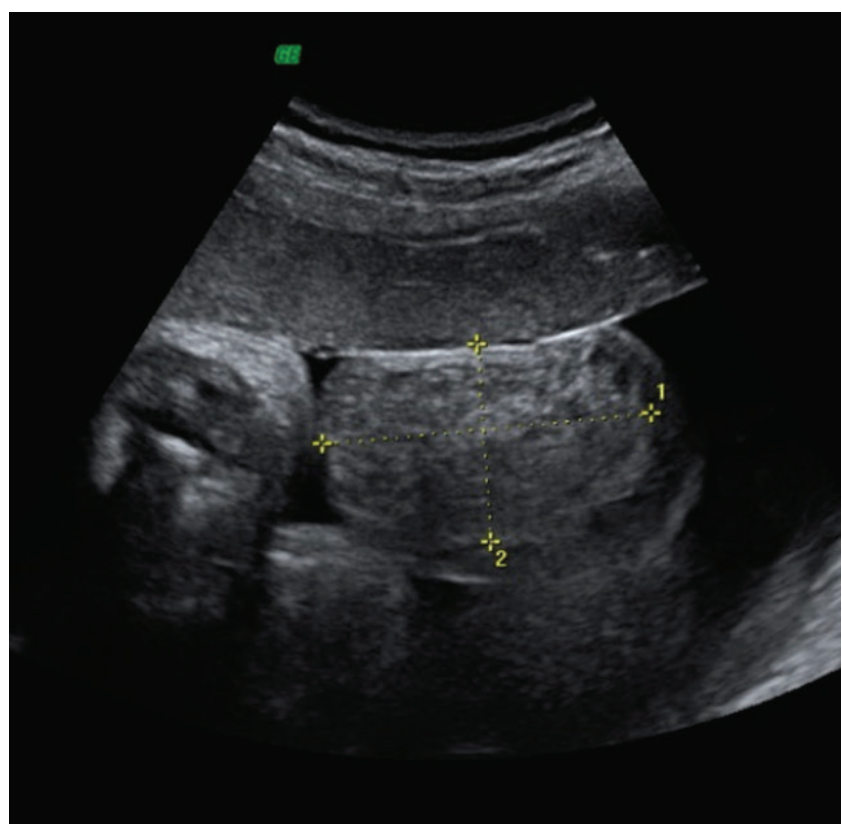

Fig. 4. Inguinoscrotal hernia visualized as a scrotal mass $(50 \times 46$ $\mathrm{mm}$ ) with mixed echostructure and regular walls, containing few small echo-free cystic areas on the right side (reprinted with permission from Massaro G, Sglavo G, Cavallaro A, Pastore G, Nappi C, Di Carlo C. Ultrasound prenatal diagnosis of inguinal scrotal hernia and contralateral hydrocele. Case Rep Obstet Gynecol 2013;2013:764579) [54]. 


\section{Obstetrics \& Gynecology Science}

Vol. 64, No. 5, 2021

Other significant pathologies include testicular agenesis, intratesticular masses, and IUTT.

\section{Cryptorchidism}

Cryptorchidism or undescended testicles involves the failure of the testes to descend permanently in their terminal scrotal position [80]. The estimated incidence at birth is 2-3.4\% $[7,17,81]$, although up to one-third of the cases resolve spontaneously during the first 3 months [81]. Seventy-five percent of the cases are usually unilateral and the undescended testes can be palpated in the inguinal canal [82]. Etiology is not clear, although a variety of risk factors such as defects in specific genes, prematurity, low birth weight, intrauterine growth restriction, alcohol consumption, and maternal smoking have been suggested [26,80,81,83-86]. The main complications include reduced fertility, an increased risk of testicular cancer, and the possibility of associated abnormalities. Evidence suggests that both the location and the time of cryptorchidism correlate with the loss of germ cells and Leydig cells [87]. Paternity rates are similar in case of unilateral cryptorchidism, but significantly lower (33-65\%) in case of bilateral cryptorchidism [88]. Cryptorchidism increases the risk of testicular cancer by 3 to 8 times [89]. Orchiopexy before adolescence reduces this risk, but it is still more than twice the risk in general population [8]. Associated abnormalities may exhibit a high incidence, with a potential risk of perinatal complications $[17,90]$. Postnatal management is extremely protocolized and there are several recent clinical guidelines on the subject $[8,91]$. The main objectives suggested by the Canadian Urological Association (CUA) guidelines include maximizing the possibility of adequate hormonal production and fertility potential, treating associated conditions, and preventing testicular torsion [8]. The CUA guidelines also insist on early detection to determine adequate follow-up and referral for specialized treatment and management. Treatment involves orchiopexy as soon as the patient is clinically stable for anesthesia between 6 and 18 months of age, although the American Urological Association prefers performing it during the first year of life [91]. Orchiectomy is reserved for cases wherein the malignant potential is significant and the testicles cannot contribute to fertility, as observed in the case of post-pubertal cryptorchidism [92].

\section{Testicular agenesis}

In case of an absent or impalpable testicle in the scrotum, it is necessary to differentiate among a testicle that is present but does not descend (cryptorchidism), a testicle that atrophies and disappears during fetal life (vanishing testis syndrome/testicular regression syndrome), and an absent testicle that never developed (congenital anorchia) $[93,94]$. Cryptorchidism is the most common congenital defect, while congenital anorchia is considered a very rare condition observed in approximately 1 in 20,000 live births [95]. In the vanishing testis syndrome, the presence of spermatic cord structures imply the presence of a testicle during early intrauterine life [93]. In addition, a normal morphology of the penis and scrotum indicates testosterone production at least until the 16th week [28]. Several theories have been suggested to explain the absence of a testicle. These include discontinuation of vascular supply, absence of development, or atrophy caused by IUTT [28]. The observation of a true vanishing testicle in the fetal scan could prevent the misdiagnosis of an impalpable testis in the postnatal period and thus, avoid the need for exploratory laparoscopy. However, in $6 \%$ of the cases, residual testicular tissue may be observed, which could be associated with an increased risk of malignant degeneration. Hence, some authors advocate the removal of blood vessels as well as the surrounding tissue in these cases [96].

\section{Testicular masses}

The incidence of prepubertal testicular neoplasms is 5 per 100,000 , which is 10 times lower than that in the postpubertal stage and fetal findings are extremely rare [97]. The most frequent histological type is the yolk sac tumor followed by teratoma, although some studies have reported the latter as the most frequent type $[18,97,98]$. However, the few published cases of prenatal diagnosis involve teratomas and granulosa cell tumors [99-102]. The cause is probably the characteristic sonographic aspect of both the entities. Teratomas appear as large complex cystic masses that are sometimes hypervascularized and show calcifications [103]. Granulosa cell tumors also exhibit a multicystic appearance [101]. In contrast, yolk sac tumors appear as discrete, circumscribed masses in the testicle [104]. Management depends on the benign or malignant behavior of the mass, although partial or total orchiectomy is a frequent treatment approach. In invasive cases, chemotherapy and radiotherapy are considered $[100,101]$. 


\section{Obstetrics \& Gynecology Science}

Álvaro López Soto, et al. Sonographic evaluation of fetal scrotum

\section{Intrauterine testicular torsion}

IUTT was previously included under perinatal torsion that occurred before 30 days of life. Currently, it is distinguished as an entity suspected in utero or in the immediate neonatal examination $[105,106]$. Due to these changes in the nomenclature, its incidence is not well known. However, at least 150 cases have been published in the literature and 22 of these were bilateral [107]. Etiology of IUTT is unknown. Some theories suggest etiological factors such as high birth weight, the trauma of a complicated birth, or an overactive crematoric reflex. However, the most popular theory suggests that the extreme mobility of the tunica vaginalis within the scrotum allows torsion due to crematoric contractions [108]. These torsions usually occur between the 34th and 38th weeks or during delivery [107]. Ultrasound signs include the absence of Doppler flow on the affected side and the appearance of enlarged and heterogeneous testicles with hypoechoic areas $[107,109]$. Accumulation of hemorrhagic fluid can also be observed between the layers of the tunica vaginalis, showing a "double ring hemorrhage" appearance, contralateral hydrocele, and deviation of the scrotal septum toward the affected side [105]. However, treatment of prenatal torsion is controversial. Most of the authors have reported that antenatal torsion represents an irreversible intrauterine phenomenon with a salvation rate of less than $5 \%$ and termination of pregnancy should be considered urgently after the diagnosis of acute cases $[6,110]$. Bilateral torsion is considered a true emergency due to the risk of an abnormality, indicating urgent surgery in the newborn $[6,111]$.

\section{Other entities}

Other notable testicular pathologies include testicular ectopia, scrotoschisis, polyorchidism, and testicular lithiasis (Fig. 5). Testicular ectopia differs from cryptorchidism in that the position of the testicle is outside the line of descent and the superficial inguinal sac is the most common location $[112,113]$. Extrusion of the testis through a scrotal defect or scrotoschisis can occur due to MPO, in which accumulation within the scrotum reaches a pressure threshold that results in rupture [29]. It can also occur due to a lack of development of the cremaster muscle [112]. Polyorchidism is characterized by the presence of more than two testicles. To date, approximately 200 cases have been reported. Among these, 7 cases exhibited the presence of 4 testicles $[112,114,115]$. Testicular lithiasis is characterized by the presence of diffuse calcifications
[51]. This is a relatively frequent finding with a prevalence of $2.9 \%$ in the United States [116]. Its management is under debate, since it is associated with several medical conditions and a 22-fold increase in the incidence of malignant tumors $[50,116]$.

\section{1) Epididymal pathologies}

Epididymis is a paratesticular structure that has not been described in prenatal ultrasound despite its important role and a high prevalence of associated abnormalities. We have included the presence of epididymal cysts, anomalies of the testicular connection, and epididymal appendages in this review. Epididymal cysts are common findings with a prevalence of $14.4 \%$ in the pediatric population, increasing up to $35.5 \%$ in children over 15 years of age [117]. Epididymal cysts contain fluid similar to that observed in the rete testis. Clinically, they are considered benign cysts that do not require further evaluation [51]. Anomalies of the connection between the epididymis and the testis have various classifications. Therefore, the data on their prevalence are variable. Favorito et al. [118] reported a prevalence of $3.44 \%$ in nor-

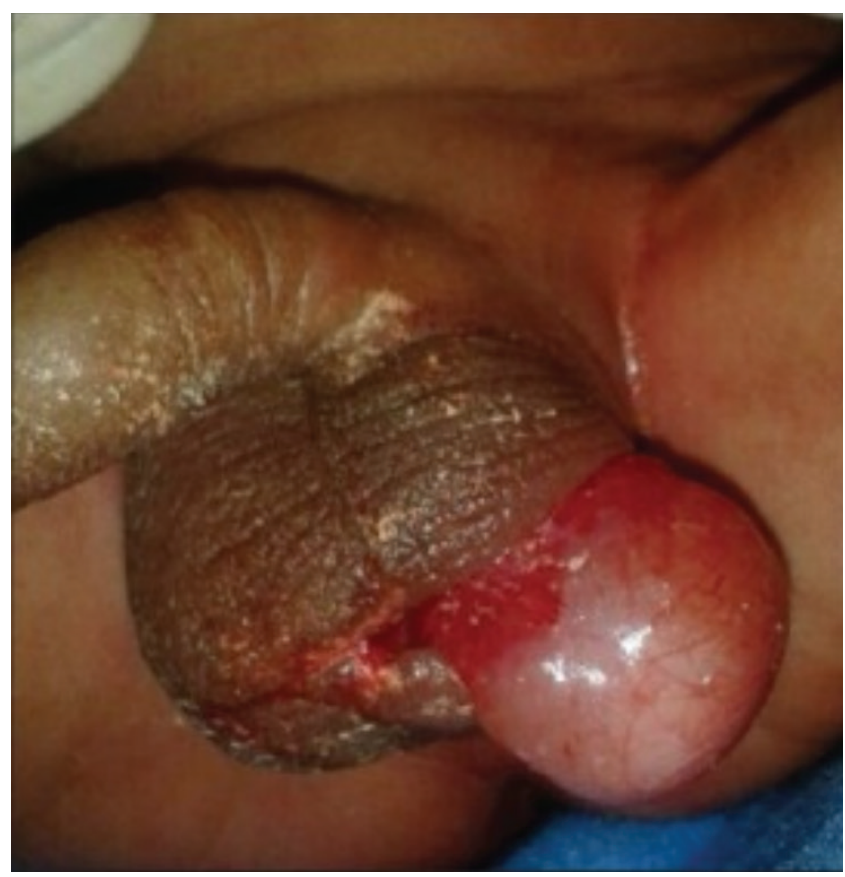

Fig. 5. Right testis extruding from the scrotum in a 15-day-old newborn, which was confirmed as scrotoschisis (reprinted with permission from Pujar VC, Joshi SS, Singh DR. Scrotoschisis: a rare cause of acute scrotum in neonates. Indian J Urol 2015;31:262-3) [119]. 


\title{
Obstetrics \& Gynecology Science
}

\author{
Vol. 64, No. 5, 2021
}

mal fetal testes and $36.12 \%$ in cryptorchid testes. The association with other anomalies, especially with cryptorchidism, has implications for future fertility as well as for the technical aspects of subsequent surgery $[118,120]$. Epididymal appendages are found in $20-24 \%$ of individuals [121]. Their functions are not well known, although it seems that they can control the amount of serous fluid in the tunica vaginalis space [122]. Torsional appendages account for $50 \%$ of the cases of acute scrotum in prepubertal boys [123].

\section{Prenatal diagnosis}

Currently, the review of the scrotum and internal structures is not established in the first-trimester and second-trimester ultrasound examinations $[1,2]$, mainly because testicular descent does not occur at least until the 24th week [4]. Moreover, they are not usually examined during the third-trimester ultrasound or in the detailed morphological examinations recommended after the diagnosis of most of the fetal abnormalities, resulting in a significant lack of knowledge about diagnosis and management of genital pathologies. This is reflected in the scientific literature predominantly consisting of clinical cases and literature focused on entities with striking ultrasound features such as MPO or penoscrotal transposition $[10,36]$. Consequently, there is a trend of significant differences between prenatal findings and postnatal prevalence, as observed in the case of benign testicular tumors, cysts, and epididymal appendages or testicular microlithiasis $[18,116]$; absence of studies about more detailed structures such as the epididymis [124]; scarce and heterogeneous normative data $[4,22]$; and a lack of management of findings such as hydrocele or undescended testicles $[27,55]$. IUTT could be the main exception to this trend, with studies focused on its diagnosis and management $[6,108,125]$. There are several benefits of evaluation of the scrotum and internal structures.

\section{Manifestation of genetic syndromes, hormonal disorders, and associated anomalies}

Malformations such as bifid scrotum, scrotal agenesis, or cryptorchidism may indicate an undervirilization process, suggesting the presence of a DSD or genetic syndromes with significant morbidity such as the Smith-Lemli-Opitz syndrome or the Prune-Belly syndrome $[126,127]$. Cryptorchidism, is a known component of almost 400 different syndromes including many with important comorbidities [8]. Similarly, the high rate of associated anomalies in multiple systems, especially in the urinary system, would require a more thorough anatomical review.

\section{Diagnosis of subsidiary pathology for immediate intervention}

In cases of IUTT at more than 34 gestational weeks, Melcer et al. [6] recommend immediate delivery and surgical intervention in unilateral affection of less than 24 hours of evolution or bilateral affection to save the compromised testicles. A meta-analysis by Monteilh et al. [125] suggested that urgent surgery should be considered if testicular viability is suspected.

\section{Diagnosis of subsidiary pathology during postnatal assessment}

Although the prenatal findings of pathologies such as inguinoscrotal hernia, MPO, or cryptorchidism cannot be adequately addressed until the postnatal stage, additional information can be obtained that might help reduce the anxiety of the parents, plan the delivery in reference centers, and prepare the medical team [7]. For example, the presence of abnormalities associated with cryptorchidism may allow planning of the surgical approach [69]. It is also possible to predict the need for postnatal surgery, to avoid unnecessary interventions, or to determine long-term fertility $[99,118,128]$.

\section{Clinical knowledge of normal variants and pathology}

It is unclear how to interpret and act on many of the incidental findings including abnormalities present in a considerable proportion of fetal population such as hydrocele (15\%), epididymal cysts (15\%), testicular appendages (20-24\%), and epididymal appendages (80-100\%) [54,56,122]. An increase in the frequency of ultrasound studies would allow formulating the patterns of action and the evidence to support them.

Similarly, evaluation of the male genitals may have unwanted effects. An increase in the findings could lead to a greater number of diagnostic tests and follow-ups, which implies an increase in the expenses as well as in the anxiety of parents and family members [51]. Nevertheless, systematic examination should be included in the third-trimester ultrasound, a test already questioned for its apparent lack of significant benefits to the mother or the baby, for the reasons already discussed in previous sections $[129,130]$. It could also lead to 


\section{Obstetrics \& Gynecology Science}

Álvaro López Soto, et al. Sonographic evaluation of fetal scrotum

complications and confusion by interfering with pathologies that are fully protocolized at the postnatal stage. For example, CUA guidelines for cryptorchidism do not recommend the use of imaging tests, as they cannot adequately discern the presence of intra-abdominal gonadal tissue or they might produce iatrogenic effects by confusing undescended testes with retractile testes [8].

\section{Conclusions}

The scrotum and internal structures show a wide range of pathologies, with varying degrees of prevalence, morbidity, and mortality. The majority of the reported cases are incidental findings, diagnosed by striking signs on ultrasound examination or detected retrospectively in the postnatal stage. Normative data or data regarding management of these entities are scarce. Active evaluation of these structures could have important benefits in the diagnosis and prenatal management, although there are disadvantages such as an increase in the number of diagnostic tests or parents' anxiety. Well-designed contemporary studies are necessary to improve our knowledge regarding this subspecialty.

\section{Conflict of interest}

No potential conflict of interest relevant to this article was reported.

\section{Ethical approval}

This study does not require approval of the Institutional Review Board because no patient data is contained in this article. The study was performed in accordance with the principles of the Declaration of Helsinki.

\section{Patient consent}

Written informed consent and the use of images from patients are not required for the publication.

\section{Funding information}

None.

\section{References}

1. Salomon LJ, Alfirevic Z, Berghella V, Bilardo C, Hernandez-Andrade $E$, Johnsen $S L$, et al. Practice guidelines for performance of the routine mid-trimester fetal ultrasound scan. Ultrasound Obstet Gynecol 2011;37:116-26.

2. Reddy UM, Abuhamad AZ, Levine D, Saade GR; Fetal Imaging Workshop Invited Participants. Fetal imaging: executive summary of a joint Eunice Kennedy Shriver National Institute of Child Health and Human Development, Society for Maternal-Fetal Medicine, American Institute of Ultrasound in Medicine, American College of Obstetricians and Gynecologists, American College of Radiology, Society for Pediatric Radiology, and Society of Radiologists in Ultrasound Fetal Imaging workshop. Obstet Gynecol 2014;123:1070-82.

3. Soto ÁL. Genital abnormalities: contextualization of a neglected area in prenatal diagnosis. Rev Colomb Obstet Ginecol 2020;71:275-85.

4. Achiron R, Pinhas-Hamiel O, Zalel Y, Rotstein Z, Lipitz $S$. Development of fetal male gender: prenatal sonographic measurement of the scrotum and evaluation of testicular descent. Ultrasound Obstet Gynecol 1998; 11:242-5.

5. Birnholz JC. Determination of fetal sex. N Engl J Med 1983;309:942-4.

6. Melcer Y, Mendlovic S, Klin B, Keidar R, Lysyy O, Herman $A$, et al. Fetal diagnosis of testicular torsion: what shall we tell the parents? Prenat Diagn 2015;35:16773.

7. Zampieri N, Zamboni C, Ghidini A, Borruto F, Camoglio FS. Prenatal sonographic evaluation of male genitalia development. Minerva Ginecol 2008;60:317-21.

8. Braga LH, Lorenzo AJ, Romao RLP. Canadian Urological Association-Pediatric Urologists of Canada (CUA-PUC) guideline for the diagnosis, management, and followup of cryptorchidism. Can Urol Assoc J 2017;11:E25160.

9. Ronzoni S, Melamed N, Kingdom JC, Ryan G, Jaeggi E, 


\title{
Obstetrics \& Gynecology Science
}

\author{
Vol. 64, No. 5, 2021
}

Windrim RC. Prenatal diagnosis of inguinoscrotal hernia associated with bowel dilatation: a pathogenetic hypothesis. Prenat Diagn 2015;35:1151-3.

10. Durmuş G, Boybeyi-Türer Ö, Gharibzadeh-Hizal M, Ekinci S, Kiper N. Meconium periorchitis: an incidentally diagnosed rare entity during inguinal herniorraphy. Turk J Pediatr 2018;60:612-4.

11. Makiyan Z. Systematization of ambiguous genitalia. Organogenesis 2016;12:169-82.

12. Marshall FF. Embryology of the lower genitourinary tract. Urol Clin North Am 1978;5:3-15.

13. Sharpe RM. Environmental/lifestyle effects on spermatogenesis. Philos Trans R Soc Lond B Biol Sci 2010;365:1697-712.

14. Sampaio FJ, Favorito LA. Analysis of testicular migration during the fetal period in humans. J Urol 1998;159:540-2.

15. Zimmermann S, Steding G, Emmen JM, Brinkmann AO, Nayernia K, Holstein AF, et al. Targeted disruption of the Insl3 gene causes bilateral cryptorchidism. Mol Endocrinol 1999;13:681-91.

16. Hutson JM, Southwell BR, Li R, Lie G, Ismail K, Harisis G, et al. The regulation of testicular descent and the effects of cryptorchidism. Endocr Rev 2013;34:725-52.

17. Fait G, Yaron Y, Shenhar D, Gull I, Har-Toov J, Jaffa AJ, et al. Sonographic detection of undescended testes in the third trimester. J Ultrasound Med 2002;21:15-8; quiz 20.

18. Delaney LR, Karmazyn B. Ultrasound of the pediatric scrotum. Semin Ultrasound CT MR 2013;34:248-56.

19. Tyloch JF, Wieczorek AP. Standards for scrotal ultrasonography. J Ultrason 2016;16:391-403.

20. Alkhori NA, Barth RA. Pediatric scrotal ultrasound: review and update. Pediatr Radiol 2017;47:1125-33.

21. Pinette MG, Wax JR, Blackstone J, Cartin A. Normal growth and development of fetal external genitalia demonstrated by sonography. J Clin Ultrasound 2003;31:465-72.

22. Rotondi M, Valenzano F, Bilancioni E, Spanò G, Rotondi M, Giorlandino C. Prenatal measurement of testicular diameter by ultrasonography: development of fetal male gender and evaluation of testicular descent. Prenat Diagn 2001;21:112-5.

23. Baskin L, Shen J, Sinclair A, Cao M, Liu X, Liu G, et al. Development of the human penis and clitoris. Differ- entiation 2018;103:74-85.

24. Malas MA, Sulak O, Oztürk A. The growth of the testes during the fetal period. BJU Int 1999;84:689-92.

25. Kaplan SL, Edgar JC, Ford EG, Adgent MA, Schall J, Kelly $A$, et al. Size of testes, ovaries, uterus and breast buds by ultrasound in healthy full-term neonates ages 0-3 days. Pediatr Radiol 2016;46:1837-47.

26. Kaleva M, Toppari J. Genetics and hormones in testicular descent. Hormones (Athens) 2003;2:211-6.

27. Nemec SF, Nemec U, Weber M, Kasprian G, Brugger $P C$, Krestan $C R$, et al. Male sexual development in utero: testicular descent on prenatal magnetic resonance imaging. Ultrasound Obstet Gynecol 2011;38:688-94.

28. Favorito LA, Klojda CA, Sampaio FJ. Congenital absence of the testis in human fetuses and in cryptorchid patients. Int J Urol 2004;11:1110-3.

29. DeRoo SE, Lumpkins KM, El-Metwally DE. Scrotoschisis in a neonate with meconium peritonitis and periorchitis. J Neonatal Perinatal Med 2016;9:107-12.

30. Inde $Y$, Terada $Y$, Ikegami E, Sekiguchi A, Nakai $A$, Takeshita T. Bifid scrotum and anocutaneous fistula associated with a perineal lipomatous tumor complicated by temporary bilateral cryptorchidism in utero mimicking ambiguous genitalia: 2-D/3-D fetal ultrasonography. J Obstet Gynaecol Res 2014;40:843-8.

31. Fahmy MA, El Shennawy AA, Edress AM. Spectrum of penoscrotal positional anomalies in children. Int J Surg 2014;12:983-8.

32. Paladini $D$, Palmieri $S$, Morelli PM, Forleo F, Morra $T$, Salviati $M$, et al. Fetal inguinoscrotal hernia: prenatal ultrasound diagnosis and pathogenetic evaluation. Ultrasound Obstet Gynecol 1996;7:145-6.

33. Stupak A, Krzyzanowski A, Semczuk-Sikora A, Dymanowska-Dyjak I, Geca T, Kondracka A, et al. Conservative management after prenatal ultrasound diagnosis of meconium periorchitis. J Med Ultrason 2014;41:499-505.

34. Suriawinata A, Talerman A, Vapnek JM, Unger P. Hemangioma of the testis: report of unusual occurrences of cavernous hemangioma in a fetus and capillary hemangioma in an older man. Ann Diagn Pathol 2001;5:80-3.

35. Lamm DL, Kaplan GW. Accessory and ectopic scrota. Urology 1977;9:149-53.

36. Sexton P, Thomas JT, Petersen S, Brown N, Arms JE, 


\section{Obstetrics \& Gynecology Science}

Álvaro López Soto, et al. Sonographic evaluation of fetal scrotum

Bryan J, et al. Complete penoscrotal transposition: case report and review of the literature. Fetal Diagn Ther 2015;37:70-4.

37. Nakamura $Y$, Jennings RW, Connolly S, Diamond DA. Fetal diagnosis of penoscrotal transposition associated with perineal lipoma in one twin. Fetal Diagn Ther 2010;27:164-7.

38. Murase N, Uchida H, Hiramatsu K. Accessory scrotum with perineal lipoma diagnosed prenatally: case report and review of the literature. Nagoya J Med Sci 2015;77:501-6.

39. Ono M, Harley VR. Disorders of sex development: new genes, new concepts. Nat Rev Endocrinol 2013;9:7991.

40. Moorthy HK, Pillai BS, Rathore RS, Mehta N. Ectopic scrotum: a unique case report. Can Urol Assoc J 2015;9:E665-6.

41. Redman JF, Bissada NK. Complete penoscrotal transposition. Urology 2007;69:181-2.

42. Wang Y, Cai A, Sun J, Li T, Wang B, Li J. Prenatal diagnosis of penoscrotal transposition with 2- and 3-dimensional ultrasonography. J Ultrasound Med 2011;30:1397-401.

43. Swartz JM, Ciarlo R, Denhoff E, Abrha A, Diamond $D A$, Hirschhorn JN, et al. Variation in the clinical and genetic evaluation of undervirilized boys with bifid scrotum and hypospadias. J Pediatr Urol 2017;13:293. e1-6.

44. Perović S, Vukadinović V. Penoscrotal transposition with hypospadias: 1-stage repair. J Urol 1992;148:1510-3.

45. Mohan PP, Woodward MN, Chandran H, Parashar K. Topical testosterone in scrotal agenesis. Pediatr Surg Int 2006;22:565-6.

46. Coplen DE, Mikkelsen D, Manley CB. Accessory scrotum located on the distal penile shaft. J Urol 1995;154:1908.

47. Nishio $H$, Mizuno $K$, Moritoki $Y$, Kamisawa $H$, Naiki T, Kurokawa $\mathrm{S}$, et al. Hemiscrotal agenesis: pathogenesis and management strategies. Int J Urol 2016;23:523-6.

48. Pinke LA, Rathbun SR, Husmann DA, Kramer SA. Penoscrotal transposition: review of 53 patients. J Urol 2001;166:1865-8.

49. Karmazyn B. Scrotal ultrasound. J Clin Ultrasound 2010;5:61-74.
50. Bushby LH, Miller FN, Rosairo S, Clarke JL, Sidhu PS. Scrotal calcification: ultrasound appearances, distribution and aetiology. Br J Radiol 2002;75:283-8.

51. Calle-Toro JS, Kelly A, Ford EJ, Zemel BS, Schall JI, Adgent $M A$, et al. Incidental findings during ultrasound of thyroid, breast, testis, uterus and ovary in healthy term neonates. J Ultrasound 2019;22:395-400.

52. Eyssartier E, Villemagne T, Maurin L, Machet MC, Lardy $\mathrm{H}$. Intrascrotal lipoblastoma: a report of two cases and a review of the literature. J Pediatr Urol 2013;9(6 Pt B):e151-4.

53. Ito $M$, Hashizume $K$, Kanamori $Y$. New phenotype of accessory scrotum with perineal lipoblastoma: coexistence of midperineal and lateral accessory scrotums. Int J Urol 2004;11:125-7.

54. Massaro G, Sglavo G, Cavallaro A, Pastore G, Nappi C, Di Carlo C. Ultrasound prenatal diagnosis of inguinal scrotal hernia and contralateral hydrocele. Case Rep Obstet Gynecol 2013;2013:764579.

55. Pretorius DH, Halsted MJ, Abels W, Catanzarite VA, Kaplan G. Hydroceles identified prenatally: common physiologic phenomenon? J Ultrasound Med 1998; 17:49-52.

56. Kim SO, Na SW, Yu HS, Kwon D. Epididymal anomalies in boys with undescended testis or hydrocele: significance of testicular location. BMC Urol 2015;15:108.

57. Berdon WE, Baker DH, Becker J, De Sanctis P. Scrotal masses in healed meconium peritonitis. N Engl J Med 1967;277:585-7.

58. Pan EY, Chen LY, Yang JZ, Lee Z, Wang ZZ. Radiographic diagnosis of meconium peritonitis. A report of 200 cases including six fetal cases. Pediatr Radiol 1983;13:199-205.

59. Rios LT, Araujo Júnior E, Nardozza LM, Caetano AC, Moron AF, Martins Mda G. Prenatal diagnosis and postnatal ultrasound findings of cloacal anomaly: a case report. Case Rep Pediatr 2012;2012:969860.

60. Wax JR, Pinette MG, Cartin A, Blackstone J. Prenatal sonographic diagnosis of meconium periorchitis. J Ultrasound Med 2007;26:415-7.

61. Ochiai D, Omori S, Ikeda T, Yakubo K, Fukuiya T. A rare case of meconium periorchitis diagnosed in utero. Case Rep Obstet Gynecol 2015;2015:606134.

62. Jeanty C, Bircher A, Turner C. Prenatal diagnosis of meconium periorchitis and review of the literature. J 


\section{Obstetrics \& Gynecology Science}

Vol. 64, No. 5, 2021

Ultrasound Med 2009;28:1729-34.

63. Acosta P, Gambina F, Perelli L, Díaz Pumará E, Martínez $J L$, Etchepareborda MN, et al. Meconium periorchitis: a case report. Arch Argent Pediatr 2015;113:e330-2.

64. Brown-Harrison MC, Harrison AM, Reid BS, Cartwright PC. Meconium periorchitis--a cause of scrotal mass in the newborn. Clin Pediatr (Phila) 2000;39:179-82.

65. Zerhouni S, Mayer C, Skarsgard ED. Can we select fetuses with intra-abdominal calcification for delivery in neonatal surgical centres? J Pediatr Surg 2013;48:94650.

66. Grosfeld JL. Current concepts in inguinal hernia in infants and children. World J Surg 1989;13:506-15.

67. Frati A, Ducarme G, Vuillard E, Pecastaing A, Yver C, Pejoan $\mathrm{H}$, et al. Prenatal evaluation of a scrotal mass using a high-frequency probe in the diagnosis of inguinoscrotal hernia. Ultrasound Obstet Gynecol 2008;32:949-50.

68. Kesby G, Beilby R, Petroni M. Fetal inguinoscrotal hernia: sonographic diagnosis and obstetric management. Ultrasound Obstet Gynecol 1997;10:359-61.

69. Allen LM, Nosovitch JT Jr, Silverman RK, Folk JJ. Prenatal diagnosis of an inguinoscrotal hernia in a fetus with cystic fibrosis. J Ultrasound Med 2004;23:1391-4.

70. Ji EK, Yoon CS, Pretorius DH. Prenatal diagnosis of an inguinoscrotal hernia: sonographic and magnetic resonance imaging findings. J Ultrasound Med 2005;24:239-42.

71. Khatib N, Goldstein I, Vitner D, Ganem N, Livoff A, Wiener Z. Prenatal diagnosis of scrotal-inguinal hernia: two case reports and review of the English literature. Eur J Obstet Gynecol Reprod Biol 2013;171:9-11.

72. Bhatt S, Ahmad M, Batra P, Tandon A, Roy S, Mandal S. Neonatal adrenal hemorrhage presenting as "Acute Scrotum"-looking beyond the obvious: a sonographic insight. J Ultrasound 2017;20:253-9.

73. Sountoulides P, Neri F, Bellocci R, Schips L, Cindolo L. Splenogonadal fusion mimicking a testis tumor. J Postgrad Med 2014;60:202-4.

74. Floyd MS Jr, Dowling CM, Power RE, O'Bien A, Gibney RG, Quinlan DM. Ectopic splenic tissue presenting as a scrotal mass. Ir J Med Sci 2007;176:141-2.

75. Khairat $A B$, Ismail $A M$. Splenogonadal fusion: case presentation and literature review. J Pediatr Surg 2005;40:1357-60.
76. Senescende L, Bitolog PL, Auberger E, Zarzavadjian Le Bian A, Cesaretti M. Adrenal ectopy of adult groin region: a systematic review of an unexpected anatomopathologic diagnosis. Hernia 2016;20:879-85.

77. Ji Y, Song B, Chen S, Jiang X, Yang G, Gao X, et al. Fetus in fetu in the scrotal sac: case report and literature review. Medicine (Baltimore) 2015;94:e1322.

78. Rescorla FJ. Pediatric germ cell tumors. Semin Pediatr Surg 2012;21:51-60.

79. Fumino S, Tajiri T, Usui N, Tamura M, Sago H, Ono S, et al. Japanese clinical practice guidelines for sacrococcygeal teratoma, 2017. Pediatr Int 2019;61:672-8.

80. Yu C, Wei Y, Tang X, Liu B, Shen L, Long C, et al. Maternal smoking during pregnancy and risk of cryptorchidism: a systematic review and meta-analysis. Eur J Pediatr 2019;178:287-97.

81. Boisen KA, Kaleva M, Main KM, Virtanen HE, Haavisto AM, Schmidt IM, et al. Difference in prevalence of congenital cryptorchidism in infants between two Nordic countries. Lancet 2004;363:1264-9.

82. Cendron M, Huff DS, Keating MA, Snyder HM 3rd, Duckett JW. Anatomical, morphological and volumetric analysis: a review of 759 cases of testicular maldescent. J Urol 1993;149:570-3.

83. Jensen MS, Wilcox AJ, Olsen J, Bonde JP, Thulstrup AM, Ramlau-Hansen $\mathrm{CH}$, et al. Cryptorchidism and hypospadias in a cohort of 934,538 Danish boys: the role of birth weight, gestational age, body dimensions, and fetal growth. Am J Epidemiol 2012;175:917-25.

84. Juul A, Almstrup K, Andersson AM, Jensen TK, Jørgensen $N$, Main KM, et al. Possible fetal determinants of male infertility. Nat Rev Endocrinol 2014;10:553-62.

85. Barrett ES, Swan SH. Stress and androgen activity during fetal development. Endocrinology 2015;156:343541.

86. Wohlfahrt-Veje C, Boisen KA, Boas M, Damgaard IN, Kai CM, Schmidt IM, et al. Acquired cryptorchidism is frequent in infancy and childhood. Int J Androl 2009;32:423-8.

87. Tasian GE, Hittelman AB, Kim GE, DiSandro MJ, Baskin LS. Age at orchiopexy and testis palpability predict germ and Leydig cell loss: clinical predictors of adverse histological features of cryptorchidism. J Urol 2009;182:704-9.

88. Lee PA, Rogol A, Houk CP. Optimizing potential for 


\section{Obstetrics \& Gynecology Science}

Álvaro López Soto, et al. Sonographic evaluation of fetal scrotum

fertility: fertility preservation considerations for the pediatric endocrinologist. Endocrinol Metab Clin North Am 2009;38:761-75.

89. Wood HM, Elder JS. Cryptorchidism and testicular cancer: separating fact from fiction. J Urol 2009;181:45261.

90. Benacerraf BR, Bromley B. Sonographic finding of undescended testes in fetuses at 35-40 weeks: significance and outcome. J Clin Ultrasound 1998;26:69-71.

91. Kolon TF, Herndon CD, Baker LA, Baskin LS, Baxter $C G$, Cheng EY, et al. Evaluation and treatment of cryptorchidism: AUA guideline. J Urol 2014;192:33745.

92. Rogers E, Teahan S, Gallagher H, Butler MR, Grainger $R$, McDermott $T E$, et al. The role of orchiectomy in the management of postpubertal cryptorchidism. J Urol 1998;159:851-4.

93. Pirgon Ö, Dündar BN. Vanishing testes: a literature review. J Clin Res Pediatr Endocrinol Endocrinol 2012;4:116-20.

94. Mangaraj S, Choudhury A, Mohanty B, Baliarsinha A. Congenital anorchia: a report of two cases and a brief review of the literature. J Integr Nephrol Androl 2017;4:141-3.

95. Tosi SE, Morin L. The vanishing testis syndrome: indications for conservative therapy. J Urol 1976;115:7589.

96. Turek PJ, Ewalt DH, Snyder HM 3rd, Stampfers D, Blyth B, Huff DS, et al. The absent cryptorchid testis: surgical findings and their implications for diagnosis and etiology. J Urol 1994;151:718-20; discussion 720-1.

97. Pohl HG, Shukla AR, Metcalf PD, Cilento BG, Retik AB, Bagli DJ, et al. Prepubertal testis tumors: actual prevalence rate of histological types. J Urol 2004;172(6 Pt 1):2370-2.

98. Pearl MS, Hill MC. Ultrasound of the scrotum. Semin Ultrasound CT MR 2007;28:225-48.

99. Youssef A, Salsi G, Curti A, Bellussi F, Elbarbary NA, Locatelli $F$, et al. Prenatal ultrasonographic features of mature cystic teratoma in undescended testicle. Ultrasound Obstet Gynecol 2016;47:527-9.

100. Peterson C, Skoog S. Prenatal diagnosis of juvenile granulosa cell tumor of the testis. J Pediatr Urol 2008;4:472-4.

101. Bulotta AL, Molinaro F, Angotti R, Ferrara F, Di Maggio G,
Bindi $E$, et al. Juvenile granulosa cell tumor of the testis: prenatal diagnosis and prescrotal approach. Ital J Pediatr 2012;38:67.

102. Illescas T, Ibba RM, Zoppi MA, luculano A, Contu R, Monni $G$. Prenatal ultrasound diagnosis of a fetal testis granulosa cell tumour. J Obstet Gynaecol 2014;34:967.

103. Janda GM, Najdzionek JS, Kozielski R, Greenfield SP, Williot PE. Early prenatal detection of an intraabdominal cryptorchid testicular teratoma. Urology 2014;83:214-6.

104. Sung EK, Setty BN, Castro-Aragon I. Sonography of the pediatric scrotum: emphasis on the Ts-torsion, trauma, and tumors. AJR Am J Roentgenol 2012;198:996-1003.

105. Herman A, Schvimer M, Tovbin J, Sandbank J, Bukovski I, Strauss S. Antenatal sonographic diagnosis of testicular torsion. Ultrasound Obstet Gynecol 2002;20:5224.

106. Das S, Singer A. Controversies of perinatal torsion of the spermatic cord: a review, survey and recommendations. J Urol 1990;143:231-3.

107. Arena F, Nicòtina PA, Romeo C, Zimbaro G, Arena S, Zuccarello B, et al. Prenatal testicular torsion: ultrasonographic features, management and histopathological findings. Int J Urol 2006;13:135-41.

108. Al-Salem AH. Intra-uterine testicular torsion: early diagnosis and treatment. BJU Int 1999;83:1023-5.

109. van der Sluijs JW, den Hollander JC, Lequin MH, Nijman RM, Robben SG. Prenatal testicular torsion: diagnosis and natural course. An ultrasonographic study. Eur Radiol 2004;14:250-5.

110. Kaye JD, Levitt SB, Friedman SC, Franco I, Gitlin J, Palmer LS. Neonatal torsion: a 14-year experience and proposed algorithm for management. J Urol 2008;179:2377-83.

111. Olguner $M$, Akgür FM, Aktuğ T, Derebek E. Bilateral asynchronous perinatal testicular torsion: a case report. J Pediatr Surg 2000;35:1348-9.

112. Togami J, Radhakrishnan J. Testicular extrusion due to scrotoschisis. Urology 2002;60:1112.

113. Kella N, Asif M, Kumar M, Laghari F, Qureshi MA. Congenital extrusion of testis (scrotoschisis). J Coll Physicians Surg Pak 2014;24 Suppl 3:S243-4.

114. Arslanoglu A, Tuncel SA, Hamarat M. Polyorchidism: 


\section{Obstetrics \& Gynecology Science}

Vol. 64 , No. 5, 2021

color Doppler ultrasonography and magnetic resonance imaging findings. Clin Imaging 2013;37:18991.

115. Alamsahebpour A, Hidas G, Kaplan A, McAleer IM. Bilateral polyorchidism with diffuse microlithiasis: a case report of an adolescent with 4 testes. Urology 2013;82:1421-3.

116. Trout AT, Chow J, McNamara ER, Darge K, Ramirez Grueso R, Munden $M$, et al. Association between testicular microlithiasis and testicular neoplasia: large multicenter study in a pediatric population. Radiology 2017;285:576-83.

117. Posey ZQ, Ahn HJ, Junewick J, Chen JJ, Steinhardt GF. Rate and associations of epididymal cysts on pediatric scrotal ultrasound. J Urol 2010;184(4 Suppl):1739-42.

118. Favorito LA, Riberio Julio-Junior H, Sampaio FJ. Relationship between undescended testis position and prevalence of testicular appendices, epididymal anomalies, and patency of processus vaginalis. Biomed Res Int 2017;2017:5926370.

119. Pujar VC, Joshi SS, Singh DR. Scrotoschisis: a rare cause of acute scrotum in neonates. Indian J Urol 2015;31:262-3.

120. Han $\mathrm{CH}$, Kang SH. Epididymal anomalies associated with patent processus vaginalis in hydrocele and cryptorchidism. J Korean Med Sci 2002;17:660-2.

121. Sahni D, Jit I, Joshi K, Sanjeev. Incidence and structure of the appendices of the testis and epididymis. J Anat 1996;189(Pt 2):341-8.

122. Józsa T, Dienes B, Telek A, Hargitai Z, Pór A, Kiss C. Differential expression of androgen and estrogen re- ceptor of appendix testis in patients with descended and undescended testes. Int J Urol 2008;15:171-4.

123. Lev M, Ramon J, Mor Y, Jacobson JM, Soudack M. Sonographic appearances of torsion of the appendix testis and appendix epididymis in children. J Clin Ultrasound 2015;43:485-9.

124. Manuel N, Ricardo P, Pilar GP, Miguel RM. Perspectives in pediatric pathology, Chapter 12. Congenital epididymal anomalies. Pediatr Dev Pathol 2016;19:12-23.

125. Monteilh C, Calixte R, Burjonrappa S. Controversies in the management of neonatal testicular torsion: a meta-analysis. J Pediatr Surg 2019;54:815-9.

126. Nowaczyk MJ, Irons MB. Smith-Lemli-Opitz syndrome: phenotype, natural history, and epidemiology. Am J Med Genet C Semin Med Genet 2012;160C(4):25062.

127. Arlen AM, Nawaf C, Kirsch AJ. Prune belly syndrome: current perspectives. Pediatric Health Med Ther 2019;10:75-81.

128. Freedman AL. Prenatal scrotal ultrasound: providing new clues in cryptorchidism. Ultrasound Obstet Gynecol 1998;11:240.

129. Bricker L, Medley N, Pratt JJ. Routine ultrasound in late pregnancy (after 24 weeks' gestation). Cochrane Database Syst Rev 2015;2015:CD001451.

130. Henrichs J, Verfaille V, Jellema P, Viester L, Pajkrt E, Wilschut J, et al. Effectiveness of routine third trimester ultrasonography to reduce adverse perinatal outcomes in low risk pregnancy (the IRIS study): nationwide, pragmatic, multicentre, stepped wedge cluster randomised trial. BMJ 2019;367:15517. 